\title{
Mobilization and isotope fractionation of chromium in Ni laterites, Indonesia
}

\author{
AKANE ITO $^{1}$, DR. TSUBASA OTAKE ${ }^{2}$, KATSUYUKI \\ YAMASHITA $^{3}$, ADI MAULANA ${ }^{4}$, KENZO SANEMATSU $^{5}$, \\ SUFRIADIN $;^{4}$, TSUTOMU SATO ${ }^{2}$ AND PROF. \\ MASAHARU TANIMIZU, PHD. ${ }^{1}$ \\ ${ }^{1}$ Kwansei Gakuin University \\ ${ }^{2}$ Hokkaido University \\ ${ }^{3}$ Okayama University \\ ${ }^{4}$ Hasanuddin University \\ ${ }^{5}$ Geological Survey of Japan, AIST \\ Presenting Author: itouakane0330@gmail.com
}

Nickel laterite which is an economically important resource for $\mathrm{Ni}$ forms by chemical weathering of ultramafic rocks under tropical to subtropical conditions. This oxidative weathering also leads to break down of $\mathrm{Cr}(\mathrm{III})$-bearing minerals (silicates and oxides) and subsequent oxidation of $\mathrm{Cr}(\mathrm{III})$, resulting in the release of toxic $\mathrm{Cr}(\mathrm{VI})$ from laterite profile to runoff [1]. Chromium stable isotope has been used as a tracer for redox processes in both anthropogenic and natural environments [2]. To better understand the factors affecting mobilization of $\mathrm{Cr}(\mathrm{VI})$ in the Ni laterites, we investigated geochemical characteristics including $\mathrm{Cr}$ isotopic composition $\left(\delta^{53 / 52} \mathrm{Cr}\right)$ of two laterite profiles with contrasting weathering intensity developed on the serpentinized peridotite in Sulawesi, Indonesia.

In both profiles, the saprolite horizons exhibit similar $\mathrm{Cr}$ contents and $\delta^{53 / 52} \mathrm{Cr}$ values $(-0.15 \%$ o to $-0.01 \%$ ) with the bedrocks ( - $0.13 \%$ ), indicating minor $\mathrm{Cr}$ mobility, while the surface samples are depleted in $\mathrm{Cr}$ with isotopically light $\mathrm{Cr}$ compositions $(\sim-0.40 \%$ o) relative to the bedrocks. These results suggest that intensive weathering has removed isotopically heavy $\mathrm{Cr}(\mathrm{VI})$ from weathering profiles, leaving light isotopes in near surface. Our isotope data for primary $\mathrm{Cr}(\mathrm{III})$-bearing minerals separated from bedrocks indicates that Cr-spinel, known as weathering residual phase, has been broken down, which may contribute to the source of isotopically heavy $\mathrm{Cr}(\mathrm{VI})$. In contrast, the laterite horizons show different $\mathrm{Cr}$ isotope behavior between the two profiles. In relatively less weathered profile, middle part of laterite horizon is enriched in heavy isotopes $(\sim+0.18 \%)$, whereas the highly weathered profile shows almost similar $\delta^{53 / 52} \mathrm{Cr}$ values throughout the profile. The former case can be explained by the transport of isotopically heavy $\mathrm{Cr}(\mathrm{VI})$ generated in near surface downward and subsequent adsorption by $\mathrm{Fe}$ (oxy)hydroxides. For the latter case, the limited isotope variation may be due to the reduction of $\mathrm{Cr}(\mathrm{VI})$ by organic matter and/or $\mathrm{Fe}^{2+}$ as indicated by the $\mathrm{Fe}$ isotope data. The present study shows that the intensive chemical weathering has led to decomposition of the $\mathrm{Cr}$ (III)-bearing minerals and $\mathrm{Cr}(\mathrm{VI})$ mobility may be controlled by the different redox conditions in near surface.

[1] Delina et al. (2020), Chem. Geol. 558, 30, 119863. [2] Qin and Wang (2017), Rev. Min. Geochem. 82, 379-408. 